Georgetown University Law Center

Scholarship @ GEORGETOWN LAW

2001

Public Health, Ethics, and Human Rights: A Tribute to the Late Jonathan Mann

Lawrence O. Gostin

Georgetown University Law Center, gostin@law.georgetown.edu

This paper can be downloaded free of charge from:

https://scholarship.law.georgetown.edu/facpub/1817

29 J.L. Med. \& Ethics 121-130 (2001)

This open-access article is brought to you by the Georgetown Law Library. Posted with permission of the author. Follow this and additional works at: https://scholarship.law.georgetown.edu/facpub

Part of the Health Law and Policy Commons, and the Human Rights Law Commons 


\section{Public Health, Ethics, and Human Rights: A Tribute to the Late Jonathan Mann}

Lawrence O. Gostin

$\mathrm{T}$ he late Jonathan Mann famously theorized that public health, ethics, and human rights are complementary fields motivated by the paramount value of human well-being. He felt that people could not be healthy if governments did not respect their rights and dignity as well as engage in health policies guided by sound ethical values. Nor could people have their rights and dignity if they were not healthy. Mann and his colleagues argued that public health and human rights are integrally connected: Human rights violations adversely affect the community's health, coercive public health policies violate human rights, and advancement of human rights and public health reinforce one another. ${ }^{1}$ Despite the deep traditions in public health, ethics, and human rights, they have rarely cross-fertilized - although there exists an important emerging literature. ${ }^{2}$ For the most part, each of these fields has adopted its own terminology and forms of reasoning. Consequently, Mann advocated the creation of a code of public health ethics and the adoption of a vocabulary or taxonomy of "dignity violations."

Mann's intellectual and emotional appeal profoundly influenced a generation of scholars, practitioners, and activists. It is now common, and fashionable, to use the discourse of public health, ethics, and human rights in social commentary and as a tool of scholarly analysis. True to Mann's vision, people in these fields collaborate much more often and express each other's language and ideas. The rhetoric of ethics and human rights is frequently applied to the theory and practice of public health.

Given the prevalence of this discourse, observers might assume that a coherent, systematic understanding of public health ethics and human rights exists or, at least, that scholars comprehend the complex relationships among the fields.

Journal of Law, Medicine \& Ethics, 29 (2001): 121-130. (C) 2001 by the American Society of Law, Medicine \& Ethics.
Certainly, when scholars stay within their own realm or expertise the arguments are sharp - e.g., philosophers discussing ethics, or international lawyers discussing human rights. However, language and ideas borrowed across disciplines are often characterized more by passion than rigor e.g., philosophers using human rights terminology, or public health or human rights workers using the language of ethics.

My claim is that Mann's vision of three complementary fields devoted to promoting human well-being will not be advanced until there is greater precision in language and thought. When scholars and practitioners use principles of human rights and ethics as a means to improve community health, they need a more rigorous approach. This article seeks to supply a greater understanding of the related fields of public health, ethics, and human rights. It maps the important features of, and issues in, these respective fields, pointing out significant similarities and differences in reasoning.

\section{Public Health}

In thinking about the application of ethics or human rights to problems in public health, it is important first to understand what we mean by "public health." How is the field defined and what is its content - its mission, functions, and services? Who engages in the practice of public health - governments, the private sector, charities, community-based organizations? What are the principal methods or techniques of public health practitioners? In truth, finding answers to these fundamental questions is not easy because the field of public health is highly eclectic and conflicted (see Table 1 ). ${ }^{4}$

\section{Defining "public health"}

Definitions of public health vary widely, ranging from the utopian conception of the World Health Organization of an 
Table 1. Public Health.

\begin{tabular}{|r|l|}
\hline Definition & Society's obligation to assure the conditions for people's health \\
\hline Mission & $\begin{array}{l}\text { To promote physical and mental health } \\
\text { To prevent disease, injury, and disability }\end{array}$ \\
\hline Functions & $\begin{array}{l}\text { To assemble and analyze community health needs } \\
\text { To develop policy informed through scientific knowledge } \\
\text { To assure the community by providing services necessary for its health }\end{array}$ \\
\hline Jurisdiction/Domain & $\begin{array}{l}\text { Narrow focus - proximal risk factors } \\
\text { Broad focus - distal social structures (e.g., discrimination, homelessness, socioeconomic status) }\end{array}$ \\
\hline Expertise/Skills & $\begin{array}{l}\text { Epidemiology and biostatistics } \\
\text { Education and communication } \\
\text { Leadership and politics }\end{array}$ \\
\hline
\end{tabular}

ideal state of physical and mental health to a more concrete listing of public health practices. Charles-Edward A. Winslow, for example, defined public health as:

the science and the art of preventing disease, prolonging life, and promoting physical health and efficiency through organized community efforts for the sanitation of the environment, the control of community infections, the education of the individual in principles of personal hygiene, [and] the organization of medical and nursing service for the early diagnosis and preventive treatment of disease. $^{5}$

More recent definitions focus on "positive health," emphasizing a person's complete well-being. ${ }^{6}$ Definitions of positive health include at least four constructs: a healthy body, high quality personal relationships, a sense of purpose in life, and self-regard and resilience. ${ }^{7}$

The Institute of Medicine, in its seminal report on the Future of Public Health, proposed one of the most influential contemporary definitions: "Public health is what we, as a society, do collectively to assure the conditions for people to be healthy."

The Institute's definition can be appreciated by examining its constituent parts. The emphasis on cooperative and mutually shared obligation ("we, as a society") reinforces that collective entities (e.g., governments and communities) take responsibility for healthy populations. Individuals can do a great deal to safeguard their health, particularly if they have the economic means to do so. They can purchase housing, clothing, food, and medical care. Each person can also behave in ways that promote health and safety by eating healthy foods, exercising, using safety equipment (e.g., seatbelts and motorcycle helmets), or refraining from smoking, using illicit drugs, or drinking alcoholic beverages excessively. Yet, there is a great deal that individuals cannot do to secure their health; to overcome whatever these barriers may be, individuals need to organize, work together, and share their re- sources. Acting alone, people cannot achieve environmental protection, hygiene and sanitation, clean air and surface water, uncontaminated food and drinking water, safe roads and products, and control of infectious disease. Each of these collective goods, and many more, is achievable only by organized and sustained community activities. ${ }^{9}$

The Institute of Medicine's definition also makes clear that even the most organized and socially conscious society cannot guarantee complete physical and mental well-being. There will always be a certain amount of injury and disease in the population that is beyond the reach of individuals or government. The role of public health, therefore, is to "assure the conditions for people to be healthy" (emphasis added). These conditions include a variety of educational, economic, social, and environmental factors that are necessary for good health. ${ }^{10}$

Most definitions share the premise that the subject of public health is the health of populations - rather than the health of individuals - and that this goal is reached by a generally high level of health throughout society, rather than the best possible health for a few. The field of public health is concerned with health promotion and disease prevention throughout society. Consequently, public health is less interested in clinical interactions between health-care professionals and patients, and more interested in devising broad strategies to prevent, or ameliorate, injury and disease.

Scholars and practitioners have long been conflicted about the "reach" or domain of public health. ${ }^{11}$ Some prefer a narrow focus on the proximal risk factors for injury and disease. Under this perspective, public health should identify risks or harms and intervene to prevent or ameliorate them. This has been the traditional role of public health, exercising discrete powers such as surveillance, infectious disease controls (e.g., screening, vaccination, partner notification, and quarantine), and sanitary measures (e.g., safe food and drinking water).

Others prefer a broad focus on the societal, cultural, and economic foundations of health. Under this perspective, public health should be more concerned with the underlying 
conditions that are associated with poor health. ${ }^{12}$ For instance, the field of public health is ultimately interested in the equitable distribution of social and economic resources because social status, race, and wealth are important determinants of health. ${ }^{13}$ This inclusive direction for public health is gaining popularity; consider how many of the federal government's health objectives for 2010 seek a reduction in health disparities. ${ }^{14}$ Public health researchers are also venturing into areas far from their traditional expertise, including violence, war, homelessness, and discrimination. ${ }^{15}$

The problem with an expansive view is that public health - as a field, as a mandate - becomes limitless, as almost everything human beings undertake affects public health. By this account, public and private activities across a wide spectrum are the work of public health. To many, this allinclusive notion of public health is counterproductive. First, by defining itself so widely, the field lacks precision. Public health becomes an all-embracing enterprise bonded only by the common value of societal well-being. Second, by adopting such a broad array of behavioral, social, physical, and environmental interventions, it lacks a discrete expertise. The public health professions consequently incorporate a wide variety of disciplines (e.g., occupational health, health education, epidemiology, and nursing) with different skills and functions. Finally, by espousing controversial issues of economic redistribution and social restructuring, the field becomes highly political. While public health practitioners like to conceive of their field as a positivistic discipline that stresses the importance of science and technique, the field is, in reality, imbued with values and influenced by interestgroup politics.

\section{Knowing the agents of public health}

If public health has such a broad meaning, then who engages in the work of public health - governments, the private sector, academia, charities, community-based organizations? At the governmental level, public health has a significant jurisdictional problem. Even the most powerful public health agency cannot exercise direct authority over the full range of activities that affect health. Many of the determinants of health are normally the province of other agencies (e.g., agencies concerned with education, agriculture, transportation, housing, child welfare, and criminal justice). Furthermore, much of the behavior that public health authorities try to change (e.g., exercise and diet) is not subject to any governmental authority's direct legal regulation. At the same time, many of the institutions that affect the public's health are not within government at all, such as managed care organizations, business and labor, community-based organizations, and academic institutions. ${ }^{16}$

Thus, before advancing public health initiatives, scholars and practitioners need to consider who will be the "drivers" of the behavioral or environmental changes they recom- mend. It matters a great deal in law and ethics who is acting, with what authority, and with what resources. For example, society is sometimes prepared to allow government to wield powers to coerce (e.g., tax, inspect, license, and quarantine) that it would not allow the private sector to do.

What are the principal methodologies of public health practitioners? Because of the field's broad sweep, the techniques of public health are highly diverse. ${ }^{17}$ For example, public health practitioners monitor health status, calling for skills in epidemiology and biostatistics; inform and educate the public, calling for skills in education and communication; and create health policy and enforce law, calling for skills in leadership and politics. This description does not account for the many areas of public health requiring expertise in domains such as infectious diseases (e.g., virology and bacteriology), the environment (e.g., toxicology), and injuries (e.g., social sciences). As the Institute of Medicine observed: "public health's subject matter ... necessitate[s] the involvement of a broad spectrum of professional disciplines. In fact, ... public health is a coalition of professions united by their shared mission." 18

\section{Public health as including ethics and human rights}

Based on what it has the potential to be, the field of public health is caught in a dilemma. If it conceives itself too narrowly, then public health will be accused of lacking vision. It will fail to see the root causes of ill health and fail to utilize a broad range of social, economic, and behavioral tools necessary to achieve healthier populations. ${ }^{19}$ At the same time, if it conceives itself too expansively, then public health will be accused of overreaching and invading a sphere reserved for politics, not science. It will lose the ability to explain its mission and functions in comprehensible terms and, consequently, to sell public health in the marketplace of politics and priorities. ${ }^{20}$

Jonathan Mann's intention clearly was to steer the field of public health in the direction of a broader, more robust agenda that would address the fundamental determinants of injury and disease. Toward this end, Mann presented a syllogism that went something like this:

1. If the mission of public health is to assure the conditions for the population's health,

2. And socioeconomic vulnerability and disparity are vital causes of morbidity and premature mortality,

3. Then public health must address the fundamental determinants of ill health.

Mann, in both his national and international work, conceived of human rights and ethics as centrally important to the work of public health. Consequently, he passionately argued that the primary function of public health is to promote dignity, reduce inequity, and raise living standards for communities everywhere. 


\section{Public Health Ethics}

The field of bioethics has richly informed the practice of medicine and decisions about the allocation of health-care resources. However, the field has not devoted the same sustained attention to problems in public health. In their discussion of personal medical services, bioethicists have stressed the salience of individuals over communities. Thus, individual autonomy and liberty often have been regarded as trump cards, superceding countervailing public interests. By conceiving informed consent and privacy as basic entitlements, bioethicists have left little room for societal claims to health and safety.

Bioethics scholars are only beginning to go beyond individual interests to explore the fundamental importance of a population's health and well-being. ${ }^{21} \mathrm{~A}$ critical unanswered question is whether public health ethics have features which are distinct from conventional bioethics. Are ethical principles, or the methods of ethical analysis, materially different when applied to populations than when applied to individual patients? In thinking about this question, it is helpful to consider public health ethics from at least three perspectives: ethics of public health (professional ethics), ethics in public health (applied ethics), and ethics for public health (advocacy ethics). See Table 2.

\section{Ethics of public health}

The ethics of public health are concerned with the ethical dimensions of professionalism and the moral trust that society bestows on public health professionals to act for the common welfare. ${ }^{22}$ This form of ethical discourse emphasizes the distinct history and traditions of the profession, seeking to create a culture of professionalism among public health students and practitioners. It instills in professionals a sense of public duty and trust. Professional ethics are role-oriented, helping practitioners to act in virtuous ways as they undertake their functions.

Many professional groups, such as physicians and attorneys, hold themselves accountable through a set of ethical guidelines, but public health professionals have no ethical code. Perhaps the explanation for the absence of an ethical code is that no single public health profession exists, but rather a variety of different disciplines. Indeed, some disciplines with a strong public health orientation have their own ethical codes, such as epidemiologists, educators, and engineers. For example, courses of study for sanitary engineers often include the ethical dimensions of civil engineering, and licensing boards impose a set of ethical criteria.

Jonathan Mann advocated the development of an ethical code, or at least a well-articulated values statement, for public health professionals. He felt this would increase the status of the field and help clarify the distinctive ethical dilemmas faced by public health professionals. Public health professionals work in a field of considerable moral ambiguity, where guidance would be instructive, but where the development of such a code of ethics would be challenging.

A public health code of ethics would have to confront the salient issue of fiduciary responsibility. To whom do public health professionals owe a duty of loyalty and how can these professionals know what actions are morally acceptable? Physicians, attorneys, and accountants have a fiduciary duty to their clients that informs their moral world. For example, client-centered professions usually adhere to the principle that the professional serves the client, advises the client fully and honestly, takes instructions from the client, and avoids acting against the client's best interests. Certainly, codes of ethics in these professions grapple with the inevitable tensions between loyalty to the client and loyalty to the public. For example, attorneys have obligations to the courts and the system of justice overall, which at times override the duty to the client.

Who is the consumer to whom public health professionals may owe a duty of loyalty? Even if consumers of public health services could be identified, does the profession owe those consumers a duty of loyalty or is the duty truly owed to the community at large? Often public health professionals regulate or coerce consumers not according to their own best interests, but the interests of others.

Table 2. Public Health Ethics.

\begin{tabular}{|c|l|}
\hline $\begin{array}{c}\text { Ethics of Public Health } \\
\text { (Professional Ethics) }\end{array}$ & $\begin{array}{l}\text { Ethical dimensions of professionalism } \\
\text { Moral trust society bestows on professionals to act for the common good }\end{array}$ \\
\hline $\begin{array}{c}\text { Ethics in Public Health } \\
\text { (Applied Ethics: }\end{array}$ & $\begin{array}{l}\text { Ethical dimensions of public health enterprise } \\
\text { Moral standing of population's health } \\
\text { Trade-offs between collective goods and individual interests } \\
\text { Social justice: equitable allocation of benefits and burdens }\end{array}$ \\
\hline $\begin{array}{c}\text { Ethics for Public Health } \\
\text { (Advocacy Ethics: Goal-Oriented, }\end{array}$ & $\begin{array}{l}\text { Overriding value of healthy communities } \\
\text { Serves interests of populations, particularly powerless and oppressed } \\
\text { Populist Ethic) }\end{array}$ \\
Methods: pragmatic and political
\end{tabular}


Do public health professionals have a duty to tell the full truth and, if so, under what standard should they be judged? Public health professionals may earnestly believe that their mission requires vigorous interventions to prevent risky behaviors (e.g., smoking) or encourage health-promoting behaviors (e.g., seeking testing and treatment). To achieve this beneficent objective, public health professionals may exaggerate the risks or benefits of a certain practice or make claims that are insufficiently grounded in science. ${ }^{23}$ Suppose that public health professionals exaggerated the risk of HIV infection among adolescents in white, middle class suburban or rural areas to decrease sexual activity? Would that be consistent or inconsistent with ethical norms? How would an ethical code address the nuanced question of "truth telling" by public health professionals?

Perhaps the public health professional's client is not the individual consumer, but rather "the community." If so, the notion of "community" is vague and fragmented. In any given situation, many different groups may claim to represent community interests. How would an "ethical" public health professional serve the community interest? Is there any reason to believe that a code of ethics could guide public health professionals on the issue of fidelity and loyalty?

\section{Ethics in public health}

A second form of public health ethics might be called ethics in public health. Ethics in public health is concerned not so much with the character of professionals as with the ethical dimensions of the public health enterprise itself. Here, scholars study the philosophical knowledge and analytical reasoning necessary for careful thinking and decision-making in creating and implementing public health policy. This kind of "applied" ethics is situation- or case-oriented, seeking to identify morally appropriate decisions in concrete cases. Scholars can helpfully apply general ethical theory and detached analytical reasoning to the societal debates common in public health.

The application of general ethical principles to public health decisions can be difficult and complicated. Since the mission of public health is to achieve the greatest health benefits for the greatest number of people, it draws from the traditions of utilitarianism or consequentialism. The "public health model," argue Buchanan and his colleagues, uncritically assumes that the appropriate mode of evaluating options is some form of cost-benefit (or cost-effectiveness) calculation - the aggregation of goods and bads (costs and benefits) across individuals. ${ }^{24}$ Public health, according to this view, appears to permit, or even to require, that the most fundamental interests of individuals be sacrificed in order to produce the best overall outcome.

This characterization misperceives, or at least oversimplifies, the public health approach. The field of public health is interested in securing the greatest benefits for the most people. But public health does not simply aggregate benefits and burdens, choosing the policy that produces the most good and the least harm. Rather, the overwhelming majority of public health interventions are intended to benefit the whole population, without knowingly harming any individuals or groups. When public health authorities work in the areas of tobacco control, the environment, or occupational safety, for example, their belief is that everyone will benefit from smoking cessation, clean air, and safe workplaces. Certainly, public health focuses almost exclusively on one vision of the "common good" (health, not wealth or prosperity), but this is not the same thing as sacrificing fundamental interests to produce the best overall outcome.

The public health approach, of course, does follow a version of the harm principle. Thus, public health authorities regulate individuals or businesses that endanger the community. The objective is to prevent unreasonable risks that jeopardize the public's health and safety - e.g., polluting a stream, practicing medicine without a license, or exposing others to an infectious disease. More controversially, public health authorities often recommend paternalistic interventions, such as mandatory seat belt or motorcycle helmet laws. Public health authorities reason that the sacrifice asked of individuals is relatively minimal and the communal benefits substantial. Few public health experts advocate denial of fundamental interests in the name of paternalism. In the public health model, individual interests in autonomy, privacy, liberty, and property are taken seriously, but they do not invariably trump community health benefits. ${ }^{25}$

The public health approach differs from modern liberalism primarily in its preferences for balancing. Public health favors the community's interests, while liberalism favors the individual's interests. Characterizing public health as a utilitarian sacrifice of fundamental personal interests is as unfair as characterizing liberalism as a sacrifice of vital communal interests. Both traditions would deny this kind of oversimplification.

Scholars in bioethics have demonstrated convincingly the power and importance of individual freedom. However, they have given insufficient attention to equally strong values of partnership, citizenship, and community. ${ }^{26} \mathrm{As}$ members of a society in which we all share a common bond, we also have an obligation to protect and defend the community against threats to its health, safety, and security. Members of society owe a duty - one to another and to all - to promote the common good. A new public health ethic should advance the idea that individuals benefit from being part of a well-regulated society that reduces risks that all members share.

There remains much work to do in public health ethics. What is the moral standing that should be attached to the collective good? Does the health of the community have a moral standing that is independent of the health of individuals within that population? Under what circumstances should 
individual interests yield to achieve an aggregate benefit for the population?

At the same time, ethics in public health raises the important issue of social justice. How can society equitably allocate benefits or services, on the one hand, and burdens or costs, on the other? Does an otherwise effective policy become unfair if it disproportionately disadvantages a racial, ethnic, or religious group? For example, public health professionals often advocate primary enforcement of seatbelt laws so police can stop a driver simply for failure to comply with the law. But what if primary seatbelt laws are enforced disproportionately against African Americans? Similarly, governmental agencies typically advocate an increase in the cigarette tax, even while knowing that the tax is highly regressive. Is it fair to disproportionately burden the poor to achieve generally lower levels of smoking in the population?

Public health professionals routinely face these and many other kinds of dilemmas that could be informed by ethics scholarship. Think about the dilemmas that occur in the everyday practice of public health. When do educational messages cross the line to become persuasion or propaganda? When does surveillance or research unacceptably interfere with privacy? Under what circumstances - consistent with free expression - can agencies restrict commercial advertising? In regulating professionals and businesses (e.g., licenses, inspections, and nuisance abatements), how much deference should agencies give to property interests? ${ }^{27}$

\section{Ethics for public health}

In addition to "professional" and "applied" ethics, it is possible to think of an "advocacy" ethics informed by the single overriding value of a healthy community. ${ }^{28}$ Under this rationale, public health authorities posit what they think is ethically appropriate, and their function is to advocate for that social goal. This populist ethic serves the interests of populations, particularly the powerless and oppressed, and its methods are principally pragmatic and political. Public health professionals strive to convince the public and its representative political bodies that healthy populations and reduced inequalities are the preferred social goals.

Public health ethics, therefore, can illuminate the field of public health in several ways. Ethics can offer guidance on (i) the meaning of public health professionalism and the ethical practice of the profession; (ii) the moral weight and value of the community's health and well-being; (iii) the recurring themes of the field and the dilemmas faced in everyday public health practice; and (iv) the role of advocacy to achieve the goal of safer and healthier populations.

\section{Human Rights}

Jonathan Mann viewed human rights as the conscience of public health. He was acutely aware that public health poli- cies can, and do, infringe on human rights. For example, a decision to compulsorily test, treat, or confine a person with tuberculosis certainly invades a sphere of autonomy or liberty. Similarly, surveillance and mandatory reporting invade a sphere of our privacy. It was for this reason that he worked on a "human rights impact assessment" to measure the human rights effects of public health policies. ${ }^{29}$

Mann also recognized that treating individuals with dignity and respect - and promoting their human rights - is essential for their health and well-being. Think about HIV prevention among vulnerable women in resource-poor countries in Africa or South America. Public health practitioners may educate them about the risks of sex and drug use. They may even distribute the means for behavior changes (e.g., condoms and sterile injection equipment). Yet, if women are culturally and economically dependent on, or physically and emotionally abused by, their husbands, they remain powerless to reduce their risk of HIV. Mann asserted that real risk reductions could be attained only by giving women more power and control over their lives. This could be achieved by advancing civil, political, social, cultural, and economic rights - e.g., enacting and enforcing antidiscrimination laws; providing genuine protection against domestic violence; reducing socioeconomic disparities; and altering divorce, property, and estate regulations.

Human rights under Mann's conception provide powerful protections of dignity and health. Yet, there is considerable imprecision in the way that modern scholars and practitioners use the language of human rights. Consider the different, but overlapping meanings of human rights. Some use human rights language to mean a set of entitlements under international law, others use human rights to mean a set of ethical standards that stress the paramount importance of individual interests, and still others use human rights for its aspirational, or rhetorical, qualities (see Table 3). A scholar is bound to be concerned when the terminology of human rights is invoked without clarifying the sense in which it is intended.

\section{The sources of human rights law}

Legal scholars and practitioners use human rights to refer to a body of international law that originated in response to the egregious affronts to peace and human dignity committed during World War II. ${ }^{30}$ The main source of human rights law within the United Nations system is the International Bill of Human Rights comprising the United Nations Charter, the Universal Declaration of Human Rights, and two international covenants of human rights. Human rights are also protected under regional systems, including those in American, European, African, and Arab countries. ${ }^{31}$

In its preamble, the United Nations Charter articulates the international community's determination "to reaffirm faith in fundamental human rights, [and] in the dignity and worth 
Table 3. Human Rights.

\begin{tabular}{|c|l|}
\hline International Law & $\begin{array}{l}\text { International Bill of Human Rights: civil and political; economic, social, and cultural } \\
\text { Treaty obligations: text and precedent }\end{array}$ \\
\hline Philosophical & $\begin{array}{l}\text { Reasoning and argumentation } \\
\text { Import of individual interests }\end{array}$ \\
\hline Aspirational/Rhetorical & $\begin{array}{l}\text { Appeal to the fundamental rights of people } \\
\text { Symbol commanding reverence and respect } \\
\text { Tool of advocacy }\end{array}$ \\
\hline
\end{tabular}

of the human person." The Charter, as a binding treaty, pledges member states to promote universal respect for, and observance of, human rights and fundamental freedoms for all, without distinction as to race, sex, language, or religion (arts. 55-56).

Jonathan Mann was born in 1947, the year the Universal Declaration of Human Rights was drafted. The Universal Declaration, adopted in 1948, built upon the promise of the Charter by identifying specific rights and freedoms that deserve promotion and protection. The Universal Declaration was the organized international community's first attempt to establish "a common standard of achievement for all peoples and all nations" to promote human rights (Preamble). It has largely fulfilled the promise of its preamble, becoming the "common standard" for evaluating respect for human rights. Although the Universal Declaration was not promulgated to legally bind member states, its key provisions have so often been applied and accepted that they are now widely considered to have attained the status of customary international law. ${ }^{32}$

The adoption of the Universal Declaration set the stage for a binding, treaty-based scheme to promote and protect human rights. The International Covenant on Civil and Political Rights (ICCPR) and the International Covenant on Economic, Social and Cultural Rights (ICESCR) were adopted in 1966 and entered into force in 1976. The United States has ratified the ICCPR, but not the ICESCR.

The rights contained in the ICCPR are principally negative or defensive in character, affording individuals a sphere of protection from government restraint. These rights, which are to be respected without discrimination, include the following: the right to life, liberty, and security of person; the prohibition of slavery, torture, and cruel, inhuman, or degrading treatment; the right to an effective judicial remedy; the prohibition of arbitrary arrest, detention, and exile; freedom from arbitrary interference with privacy, family, or home; freedom of movement; freedom of conscience, religion, expression, and association; and the right to participate in government.

The Universal Declaration of Human Rights characterizes economic, social, and cultural rights as "indispensable for [a person's] dignity and the development of his personal- ity" (art. 22). The ICESCR forms the foundation for "positive rights" - that is, those requiring affirmative duties of the state to provide services. ${ }^{33}$ Such positive rights include the right to social security, the right to education, the right to work, the right to receive equal pay for equal work and to remuneration ensuring "an existence worthy of human dignity," and the right to share in the cultural life of the community and "to share in scientific advancement and its benefits" (arts. 22-27). Article 12 of the document requires governments to recognize "the right of everyone to the highest attainable standard of physical and mental health." Article 25 of the Universal Declaration also expressly recognizes a right to health:

Everyone has the right to a standard of living adequate for the health and well-being of himself and his family, including food, clothing, housing and medical care and necessary social services, and the right to security in the event of unemployment, sickness, disability, widowhood, old age or other lack of livelihood in circumstances beyond his control.

The two international covenants diverge in their treatment of permissible limitations. The ICCPR recognizes that certain rights are so fundamental as to be absolute and it proscribes any derogation of them. Non-derogable rights include the right to life (art. 6); freedom from torture and from cruel, inhuman, or degrading treatment or punishment (art. 7); the right to recognition as a person before the law (art. 16); and freedom of thought, conscience, and religion (art. 18). The ICCPR states that other rights may be justifiably limited under certain conditions. Freedom of movement, for example, may be justifiably limited where restrictions are "provided for by law, are necessary to protect national security, public order, public health or morals or the rights and freedoms of others" (art. 12.3).

The ICESCR, on the other hand, permits "such limitations as are determined by law only in so far as this may be compatible with the nature of these rights and solely for the purpose of promoting the general welfare in a democratic society" (art. 4). 


\section{Invoking "human rights"}

The notable features of human rights law are that it follows a set of internationally agreed-upon rules specified in the text of treaties and other instruments, is informed by precedent, and is interpreted by tribunals and commissions. International human rights law seldom provides easy answers, but, rather, struggles to define and enforce human rights in the context of the legitimate powers of governments and the needs of communities.

Ethicists use the language of human rights for related, but different purposes. The fields of ethics and human rights share an abiding belief in the paramount importance of individual rights and interests, but beyond that, their perspectives diverge. While human rights scholars stress the importance of treaty obligations, ethicists seldom refer to international law doctrine. While human rights scholars rely on text and precedent, ethicists employ philosophical reasoning and argumentation. Consequently, when ethicists adopt the language of international human rights, there is bound to be a certain amount of confusion. For example, if an ethicist claims that health care is a "human right," does she mean that a definable and enforceable right under international law exists, or simply that philosophical principles such as justice support this claim?

Finally, public health students, as well as the lay public, often use the language of human rights for its aspirational, or rhetorical, qualities. Major public health schools, such as the Johns Hopkins University and Harvard University, give their students a copy of the Universal Declaration of Human Rights at commencement or offer special certificates in human rights. When "rights" language is invoked, it is intended to convey the fundamental importance of the claim. It expresses the idea that government should adhere to certain standards, or provide certain services, because it is right and just to do so. "Human rights," when it is invoked in argument or reasoning, commands reverence and respect. Used in this aspirational sense, human rights does not need to be supported by text, precedent, or reasoning; it is self-evident and government's responsibility simply is to conform.

"Human rights," then, has features in common with "ethics," but human rights and ethics are different fields. Human rights, like ethics, is often concerned with individual rights and interests, and like "advocacy ethics," "human rights" conveys a sense of moral certainty. However, international human rights is also quite distinct from ethics. The field of human rights is based on a body of rules and precedents which are intended to express binding duties. It is complex and evolving, usually rejecting easy resolutions to the conflict between individual interests and collective goods.

The field of human rights has much work to do if it is to usefully contribute to health policy analysis. For example, human rights scholars and advocates have not clarified the meaning of the right to health. ${ }^{34}$ The conceptualization of health as a human right, and not sim- ply a moral claim, suggests that states possess binding obligations to respect, defend, and promote that entitlement. ${ }^{35}$ Considerable disagreement exists, however, as to whether "health" is a meaningful, identifiable, operational, and enforceable right, or whether it is merely aspirational or rhetorical. A right to health that is too broadly defined lacks clear content and is less likely to have a meaningful effect. For example, if health is, in the World Health Organization's words, truly "a state of complete physical, mental and social well-being," then it can never be achieved. Even if this definition were construed as a reasonable, as opposed to an absolute, standard, it remains difficult to implement, and is unlikely to be justiciable.

Vast scholarship and litigation in international forums were required to define and enforce civil and political rights. Social and economic rights, notably the right to health, deserve the same rigorous and sustained attention..$^{36}$ This, too, is beginning to happen in international forums. ${ }^{37}$ For example, the United Nations Committee on Economic, Social, and Cultural Rights recently offered detailed guidance on the meaning of the right to health. ${ }^{38}$

\section{The Legacy of Jonathan ManN}

This article pays tribute to Jonathan Mann, but argues that much work is needed to advance his vision of three fields dedicated to the single purpose of human well-being. Mann demonstrated that public health, ethics, and human rights have similar objectives and are interrelated. The field of public health is not solely a scientific pursuit, but should be imbued with the values of ethics and human rights. Consequently, public health workers need guidance in their professional roles and daily work. Philosophers, however, have rarely helped to explain the important ethical dimensions of public health. With important exceptions, ethical discourse has focused narrowly on biological medicine and individual autonomy. Ethical analysis will not enrich the theory and practice of public health unless it expands its perspective to consider the equally important values of community, mutual security, and solidarity.

Mann similarly demonstrated that people cannot be fully healthy if they do not have human rights. Affording individuals their rights can be a powerful public health strategy, freeing them from physical or emotional abuse, social stigma, and economic dependence. Human rights scholars and advocates have given sustained attention to problems of discrimination, invasion of privacy, and loss of personal liberty. However, the field has devoted much less attention to social, economic, and cultural rights - notably the right to health.

Mann enunciated important and enduring ideas, but public health, ethics, and human rights (as well as the relationships among these fields) are more complex than he indicated. Public health itself is conflicted in its mission and functions, while ethics and human rights have only begun to 
consider problems relevant to public health. The terminology in these fields may be used interchangeably, but there is a lack of clarity, precision, and consistency. Even the relationships among the fields are not as compatible as we have been led to believe. Is the individualistic thinking inherent in ethics and human rights always consistent with public health's focus on collective well-being? Can the concentration on personal rights and civil liberties actually impede the goals of public health? If so, what analytical tools are available to help reconcile the inevitable conflicts and trade-offs? These are among the many challenges left by the giant legacy of Jonathan Mann.

\section{ACKNOWLEDGMENTS}

This article is based on a book, Public Health Law and Ethics: A Reader (University of California Press and the Milbank Memorial Fund, forthcoming 2002). The Reader is a companion text to Public Health Law: Power, Duty, Restraint (University of California Press and the Milbank Memorial Fund, 2000). I am grateful to several groups that have recently met to discuss public health ethics: the Hastings Center, the Association of Schools of Public Health, the Public Health Leadership Society, and a faculty consortium from Georgetown University, the Johns Hopkins University, and the University of Virginia. I am grateful to Daniel Callahan, Jack Dillenberg, Ruth Faden, Bruce Jennings, Jeffrey Kahn, Mike Sage, and Jim Thomas. I am also grateful to the FrançoisXavier Bagnoud Center for Health and Human Rights at Harvard University for carrying on Mann's legacy, particularly Stephen P. Marks, Sofia Gruskin, and Jennifer Leaning. Most of all, I want to acknowledge and pay tribute to the work of my dear friend Jonathan Mann and his wonderful family - Naomi, Lydia, and Aaron Mann, Marie-Paule Bondat, and Mary Lou Clements.

\section{REFERENCES}

1. J. Mann, L.O. Gostin, S. Gruskin et al., "Health and Human Rights," Joumal of Health do Human Rights, 1 (1994): 6-23.

2. J.M. Mann, S. Gruskin, M.A. Grodin, and G.J. Annas, eds., Health and Human Rights: A Reader (New York: Routledge, 1998).

3. J. Mann, "Medicine and Public Health, Ethics and Human Rights," Hastings Center Report, 27 (May-June 1997): 613.

4. R. Beaglehole and R. Bonita, Public Health at the Crossroads: Achievements and Prospects (New York: Cambridge University Press, 1997).

5. C.A. Winslow, "The Untilled Fields of Public Health," Science, 9 (January 1920): 20-30, at 30.

6. "Putting Public Health Back into Epidemiology," Editorial, Lancet, 350 (1997): 229.

7. C.D. Ryff and B. Singer, "The Contours of Positive Health," Psychological Inquiry, 9 (1998):1-28; J.W. Rowe and R.L. Kahn, Successful Aging (New York: Pantheon Books, 1998). 8. Institute of Medicine, The Future of Public Health
(Washington, D.C.: National Academy Press, 1988): at 19

9. L.O. Gostin, "Public Health Law in a New Century: Part I: Law as a Tool to Advance the Community's Health," Journal of the American Medical Association, 283 (2000): 2837-41.

10. Institute of Medicine, Health and Behavior: The Interplay of Cells, Self and Society (Washington, D.C.: National Academy Press, forthcoming in 2001).

11. See G. Mooney, "Book Review," Journal of Health Politics, Policy o Law, 25 (2000): 775 (discussing the debate in Britain in the 1840s between non-physician Sir Edwin Chadwick, architect of a public health system focused on the water supply and sewage system, and Dr. William Alison, who emphasized lack of food, clothing, warmth, and adequate shelter as causes of disease).

12. I.H. Meyer and S. Schwartz, "Social Issues as Public Health: Promise and Peril," American Journal of Public Health, 90 (2000): 1189-91 (discussing the role of public health in addressing the "social ills rooted in distal social structures").

13. M. Marmot and R.G. Wilkinson, eds., Social Determinants of Health (New York: Oxford University Press, 1999).

14. Healthy People 2010: Conference Edition (Washington, D.C.: U.S. Department of Health and Human Services, 2000).

15. W.R. Breakey, "It's Time for the Public Health Community to Declare War on Homelessness," American Journal of Public Health, 87 (1997): 153-55.

16. L.O. Gostin, S. Burris, and Z. Lazzarini, "The Law and the Public's Health: A Study of Infectious Disease Law in the United States," Columbia Law Review, 99 (1999): 59-137.

17. A. Sommer and M.N. Akhter, "It's Time We Became a Profession," American Journal of Public Health, 90 (June 2000): $845-46$.

18. See Institute of Medicine, supra note 8.

19. M.J. McGinnis and W.H. Foege, "Actual Causes of Death in the United States," Journal of the American Medical Association, 270 (November 10, 1993): 2207-12.

20. S. Burris, "The Invisibility of Public Health: PopulationLevel Measures in a Politics of Market Individualism," American Joumal of Public Health, 87 (October 1997): 1607-10.

21. B. Steinbock and D.E. Beauchamp, eds., New Ethics for the Public's Health (New York: Oxford University Press, 1999); P. Bradely and A. Burls, eds., Ethics in Public and Community Health (New York: Routledge, 2000); S.S. Coughlin and T.M. Beauchamp, eds., Ethics and Epidemiology (New York: Oxford University Press, 1996).

22. D. Callahan, ed., Promoting Health Behavior: How Much Freedom? Whose Responsibility? (Washington, D.C.: Georgetown University Press, 2000).

23. D. Wikler and D.E. Beauchamp, "Health Promotion and Health Education," in W.T. Reich, ed., Encyclopedia of Bioethics, revised edition (New York: Macmillan, 1995): at 1126, 1128.

24. A. Buchanan et al., From Chance to Choice (Cambridge: Cambridge University Press, 2000): at 11-14, 55-60.

25. L.O. Gostin, "Public Health Law in a New Century: Part III: Public Health Regulation: A Systematic Evaluation," Journal of the American Medical Association, 283 (2000): 3118-22.

26. D.E. Beauchamp, The Health of the Republic: Epidemics, Medicine, and Moralism as Challenges to Democracy (Philadelphia: Temple University Press, 1998).

27. L.O. Gostin, Public Health Law: Power, Duty, Restraint (Berkeley and New York: University of California Press and the Milbank Memorial Fund, 2000).

28. B. Jennings, Presentation at Hastings Center Meeting on Ethics and Public Health, The Hastings Center, Garrison, New York (May 10, 2000).

29. L.O. Gostin and J. Mann, "Towards the Development of 
a Human Rights Impact Assessment for the Formulation and Evaluation of Health Policies," Journal of Health and Human Rights, 1 (1994):58-81.

30. G.J. Annas, "Human Rights and Health - The Universal Declaration of Human Rights at 50," New England Journal of Medicine, 339 (1998): 1777-81.

31. L.O. Gostin and Z. Lazzarini, Public Health and Human Rights in the HIV Pandemic (New York: Oxford University Press, 1997).

32. B.H. Weston and S.P. Marks, eds., The Future of International Human Rights: Commemorating the 50th Anniversary of the Universal Declaration of Human Rights (Ardsley, New York: Transnational, 2000).

33. A.R. Chapman, ed., Health Care Reform: A Human Rights Approach (Washington, D.C.: Georgetown University Press, 1994).
34. S.D. Jamar, "The International Human Right to Health," Southern University Law Review, 22 (Fall 1994): 1-68.

35. V.A. Leary, "The Right to Health in International Human Rights Law," Health $\mathfrak{G}$ Human Rights, 1 (Fall 1994): 24-56.

36. L.O. Gostin, "Human Rights of Persons with Mental Disabilities: The European Convention of Human Rights," International Journal of Law and Psychiatry, 23 (2000): 125-59.

37. B.C.A. Toebes, The Right to Health as a Human Right in International Law (Antwerpen: Intersentia/Hart, 1999).

38. United Nations Committee on Economic, Social, and Cultural Rights, "General Comment No. 14: The Right to the Highest Attainable Standard of Health," 22nd Session, April 25-May 12, 2000; L.O. Gostin, "The Right to the Highest Attainable Standard of Health," Hastings Center Reports, forthcoming 2001. 